\title{
SURVEYING CONSUMER ACCEPTANCE OF TEXTILE PRODUCTS WITH FRAGRANCE FINISH: A DETAILED REVIEW
}

\author{
Astuti Khan ${ }^{1 *}$, Gaurav Kumar ${ }^{2}$ \\ ${ }^{1}$ Department of Fashion Technology, National Institute of Fashion Technology, \\ Mumbai, Maharashtra, India \\ 2 Department of Mechanical Engineering, School of Engineering, \\ Cochin University of Science and Technology, Kochi, Kerala, India \\ *e-mail: astutikhan99@gmail.com
}

Review paper

UDC: $677+687-026: 339.1: 366.1$ doi: $10.5937 /$ tekstind $2104037 \mathrm{~K}$

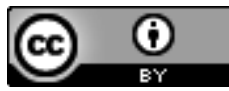

\begin{abstract}
Fragrance finishing of textiles is an area with untapped potential which has been growing at an enormous rate. The use of scents to change moods, evoke emotions and stimulate certain senses has been there for ages. Building up from that, textiles have started being infused with scents and used in domestic and industrial application. The purpose of this research is to cover all aspects of fragrance finishing. The literature review covers extensive topics like the basic concept of aromatherapy, needs of fragrance finishing, application methods and our current market scenario. The latter part of this study deals with a survey that sheds light on the research gap identified as lack of market awareness and acceptance. Chi-square was the statistical tool used for relating factors like gender, age group and income group to buying behaviour of people when it comes to fragrance finished textile products.
\end{abstract}

Keywords: aromatherapy, textile finish, fragrance finish, cosmetotextile, infused textiles.

\section{ISTRAŽIVANJE POTROŠAČA O PRIHVATANJU TEKSTILNIH PROIZVODA SA MIRISNOM DORADOM: DETALJAN PREGLED}

Apstrakt: Dorada tekstila mirisom je područje s neiskorištenim potencijalom koje raste ogromnom brzinom. Korišćenje mirisa za promenu raspoloženja, izazivanje emocija i stimulisanje određenih čula postoji već godinama. Nadograđujući to, tekstil je počeo da se infuzira mirisima i koristi u domaćoj i industrijskoj primeni. Svrha ovog istraživanja je pokriti sve aspekte završne obrade mirisa. Pregled literature pokriva opsežne teme poput osnovnog koncepta aromaterapije, potreba dorade mirisom, metoda nanošenja i našeg trenutnog tržišnog scenarija. Poslednji deo ove studije bavi se anketom koja osvetljava jaz u istraživanju identifikovan kao nedostatak svesti o tržištu i prihvaćenosti. Hi-kvadrat je bio statistički alat koji se koristi za povezivanje faktora poput pola, starosne grupe i grupe prihoda sa ponašanjem ljudi u kupovini kada su u pitanju mirisni gotovi tekstilni proizvodi.

Ključne reči: aromaterapija, završna obrada tekstila, završna obrada mirisa, kozmetički tekstil, infuzijski tekstil.

\section{INTRODUCTION}

The advances in the textile segment have been commendable over the last decade. From the use of new dyes and printing techniques to applying special chemical/natural finishes to fabrics, the average consumer nowadays has a lot to choose from. The exceeding importance that general masses are giving to beautification, health and externally appealing properties has given a boost to chemically engineered textiles and products. In line to that, chemical product design (CPD) is something which is birthed from changing customer needs and the upcoming generation to satisfy target specifications and performance. [1-5] Various books [1-3] also highlight the need of 
adapting chemical engineering ( $\mathrm{ChE}$ ) processes to the new times of aware consumers that constantly demand more.

To answer the need of new and innovative textile products, functional and value-added aspects are being incorporated extensively. Such products can be made by using new technology, chemicals and finishes. They can also be made by chemically processing ordinary textiles, to make them have extra-ordinary functional properties. [6, 7]

How does fragrance finish come into the picture? Our sense of smell is 10,000 times more active than other senses and the reaction time to a particular time of scent is immediate. As reported by researchers, use of perfumes or other forms of fragrances have a long history in relations to human beings. [8]

Various papers talk about how fragrance finish can be used for boosting fabric popularity. One such paper [9] highlights how the typical kerosene-like smell of certain chemicals added during jute processing, affect consumer's acceptance of jute-based products. This scenario poses a significant issue when it comes to various such processed textiles used for products like home textiles and related products.

Apart from refining chemically processed textile products, research has also been done in how fragrance finish in textiles (especially scents like lavender) can lead to a good sensory and emotional response from the end consumer $[10,11]$. On the aesthetic side of fragrance finishing too, the applications are diverse. Home textiles such as bed- sheets, curtains, towels, pillowcases, quilt covers, etc. are suitable for being treated with scents like lavender, rose and sandal, thus helping in eliminating tiredness and fatigue [12]

Tapping into this category of textiles and apparels shows great potential for exploration and growth. [13] Recently, fragrances have become available that can be readily added on the textiles and after finishing and fixation, they emit a pleasant fragrance. The role of the textile finisher has become very demanding. It now requires the right balance between the compatibility of different finishing products and treatments and the application processes used to provide textiles with desirable properties, so that a good profit is made and the consumer is impressed too.

Even after all of these benefits and interesting applications, properties like fabric performance, durability of the fragrance and laundering properties pose an area of concern. Different scents affect these properties in different ways [12] sure, but the real question not widely addressed by many is the consumer acceptance of these textile products.

This paper specifically goes into reviewing fragrance finishing as a milestone in chemical finishing of textiles. A survey showcases consumer behaviour and preferences for the same, while statistical analysis has been carried out to highlight certain factors that might or might not affect buying behaviour when it comes to purchasing such products. The real challenge is making a product worth the money being spent on its purchase.

\section{REVIEW OF LITERATURE}

\subsection{Textile Finishing}

Textile Finishing is a part of fabric manufacturing wherein the material is subject to different types of physical and chemical treatments. These treatments may impart aesthetic, sensory or functional value additions to the fabric. [14]

\subsubsection{Fragrance Finish}

Aromatherapy is quickly becoming a favourite form of complementary and alternative medicine (CAM). With the upcoming advancements in this sector, one can attempt self-therapy at home too. Especially when it is introduced through textile products, aromatherapy is made easy wherever needed. Micro-encapsulation can effectively control the release rate of the fragrance compounds and essential oils as required, thus keeping a check on longevity of volatile substances as well. [15]

\subsubsection{Effects of fragrance}

Over the last decade, a lot of research has been done across various countries over how fragrance affects the human mind. The research spanned over a considerable effect fragrance had on a human's feelings, emotions, moods and even physiological and cognitive factors [16].

Another researcher, Belaiche, carried out a series of experiments to observe the effect of 42 essential oils on 12 of the most common pathogenic microorganisms. He observed that essential oils with a higher Aromatic Index could help in preventing some of these pathogens [19]. Certain researches were also carried out on human volunteers [20] and even mice [21] to see the relaxing or stimulating effect that certain scents like lavender brought out. Furthermore, interesting studies were also carried out that showcased the influence of certain odours over the mental state and even arousal state of humans [22]. 
Table 1: The pharmaceutical effects of essential oils $[17,18]$

\begin{tabular}{|c|c|}
\hline Effects & Essential Oils \\
\hline Sedation & Mint, Onion, Lemon, Metasequoia \\
\hline Coalescence & Pine, Clove, lavender, Onion, Thyme \\
\hline Diuresis & Diuresis Pine, lavender Onion. Thyme, Fennel, Lemon, Metasequoia \\
\hline Facilitating & Menses Pine, lavender. Mint, Rosemary, Thyme, Basil, Chamomile, Cinnamon, \\
\hline Dismissing & Sputum Onion, Citrus, Thyme, Chamomile, lemon \\
\hline Allaying a fever & Ginger, Fennel, Chamomile, Lemon \\
\hline Curing Hypertension & Lavender, Oregano, Basil, Chamomile \\
\hline Be good for stomach & Pine, Ginger, Clove, Mint, Onion, Citrus, Rosemary, Thyme, Fennel, Basil, Cinnamon \\
\hline Diaphoresis & Lavender, Rosemary, Thyme, Chamomile, Metasequoia, pine \\
\hline Expelling wind & Ginger, Clove, Onion, Citrus, Rosemary, Fennel, Lemon \\
\hline Losing weight & Onion, Cinnamon, Lemon \\
\hline Relieving pain & Vanilla, lavender. Mint, Onion, Citrus, Rosemary, Chamomile, Cinnamon, Lemon \\
\hline Detoxification & Lavender \\
\hline Curing diabetes & Vanilla, Onion, Chamomile, Lemon \\
\hline Stopping diarrhoea & Vanilla, Ginger, Clove, lavender. Mint, Onion, Oregano, Rosemary, Thyme, \\
\hline Curing rheumatism & Lavender, Onion, Citrus, Rosemary, Thyme, Metasequoia \\
\hline Urging sexual passion & Pine, Ginger, Clove, Mint, Onion, Rosemary, Thyme, Fennel, Relieving \\
\hline Promoting appetite & Clove, lavender, Mint, Onion, Citrus, Rosemary, Fennel Basil, Chamomile, \\
\hline Relieving cough & Rosemary \\
\hline
\end{tabular}

Table 2: The sedative effects/emotions associated with essential oils [23]

\begin{tabular}{|l|l|}
\hline Emotion & Essential Oils with the Sedative Effects \\
\hline Anxiety & Benzoin, Lemon, Chamomile. Rose, Cardamom, Clove, Jasmine \\
\hline Lament & Rose \\
\hline Stimulation & Camphor, Balm oil \\
\hline Anger & Chamomile, Balm oil. Rose, Ylang Ylang \\
\hline Wretchedness & Basil, Cypress, Mint, Patchouli \\
\hline Allergy & Chamomile, Jasmine, Balm oil \\
\hline Distrustfulness & Lavender \\
\hline Tension & Camphor, Cypress, Vanilla. Jasmine. Balm oil. Lavender, Sandalwood \\
\hline Melancholy & Basil, Lemon, Chamomile, Vanilla, Jasmine, Lavender, Mint, Rose \\
\hline Hysteria & Chamomile, Balm oil, Lavender, Jasmine \\
\hline Mania & Basil, Jasmine, Pine \\
\hline Irritability & Chamomile, Camphor, Cypress, Lavender \\
\hline Desolation & Jasmine, Pine, Patchouli, Rosemary \\
\hline
\end{tabular}

\subsubsection{Needs of Fragrance Finish}

Almost every culture has combined aromatherapy with textiles for human use, and successfully so. Egyptians seem to have pioneered this area by extracting aromatic plant material and incorporating the same into textiles by using sun for infusing the same. Eu- ropeans used aromatherapy to ward off plagues and other airborne infections by the use of aromatherapy in medieval times [15].

In between burning aromatic herbs to protect against prevalent diseases [24] and incorporating a signature fragrance for couture, aromatherapy be- 
came popular and so did the relevance of fragrance finishing. The textile industry, especially the Korean textile industry, started investing into functional fragrant finishing like stress-relieving scents in business outfits and kids' clothing to relaxing scents in bed linens and bedroom textiles [25].

The developments of the aromatherapy phenomenon diversified along four basic avenues [18]:

- Medical and holistic medical aromatherapy (especially France)

- Popular and esoteric aromatherapy (majorly western societies)

- Aromatherapy applied during massage (popular in Great Britain)

- Scientific study of fragrance, as encouraged by the Fragrance Research Fund

\subsubsection{Application of fragrance finish}

Now that the importance and highly influential abilities of fragrance have been mentioned, application methods of the same on fabric need to be listed. There are 3 primary methods for the same, as discussed in detail below:

\subsection{Padding}

The fabric is padded with the fragrance solution. Padding pressure $2 \mathrm{~kg} / \mathrm{cm} 2$. It is dried and cured at $70^{\circ} \mathrm{C}-120^{\circ} \mathrm{C}(1-5 \mathrm{~min}$.). The fragrance solution used for this process is $10 \%$ the weight of fabric $[26,27,28]$.

\subsection{Jet Spray}

Exhaust at $40^{\circ} \mathrm{C}$ for 20 - 30 min (fragrance is sprayed by means of a spray gun). Amount of fragrance solution used is $5-10 \%$ of the weight of fabric $[26,27,28]$.

\subsubsection{3. $\beta$-microencapsulation}

$\beta$-cyclodextrin is used as an inclusion complex. The fragrance with $\beta$-cyclodextrin inclusions are formed by mixing a solution containing alcohol and distilled water in 1:3 ratio. The solution is emulsified with a high-speed mixer at a speed of about 10,000 rpm for 5-8 minutes. The emulsified system is transferred into a flask. The fragrance alcohol solution is added into the emulsified solutions and stirred at a temperature of $40^{\circ} \mathrm{C}$ for around 2 hours $[29,30,31]$.

\subsection{Advantages of fragrance finishing}

- Protection of the enclosed fragrance or essential oil, imparting aromatherapy

- Improved storage life
- Conversion of a liquid component to a dry solid form

- Odour masking and dust control

- Controlled diffusion of fragrance

- The tearing strength of the fabric increases $[32,33,34]$.

\subsection{Disadvantages of fragrance finishing}

- Fully durable fragrance finish hasn't been achieved yet

- Majority fall under semi-durable category

- Air permeability decreases

- Stiffness is more due to added layer/component on textile base $[32,33,34,35]$.

\subsection{Market Scenario}

There are various companies like Resil Chemicals Pvt. Ltd., Archroma India Pvt. Ltd., SAREX, etc. that are trying to make a name for themselves in this area.

Resil Chemicals Pvt. Ltd. uses a trademarked technology called Celessence that encapsulates fragrance molecules and applies them to fabric. The molecules get released on movement and the durability of this finish is 10 washes.

SAREX has a concept called Superfresh that provides Lavender, Jasmine and Rose scent for application. Tanatex Chemicals Pvt. Ltd. provides additional scents like coffee, limone, strawberry and vanilla bouquet, through a trademark technology called Bayscent.

All in all, there are many chemical finishing companies (Indian and international) that are delving into this interesting concept as there is less competition and more scope for creative value addition.

\subsection{Research Gaps and Objectives}

There is enough evidence to support that fragrance finish is something new and creative and has a huge potential to become a best-selling product. Also, the effects of different types of fragrances were taken into consideration and their impacts on the human mind and body.

Out of all the literature used for review, it was observed that the market acceptance of fragrance finishes was a topic that wasn't covered in-depth.

The objective of this research is to identify the awareness and acceptance of textile products with fragrance finish in the market. It also aims at correlating personal factors to the buying behaviour of the consumer, using statistical tools. 


\section{PROPOSED METHODOLOGY}

The methodology followed was a survey to evaluate responses and figure out exactly what contributes to a customer's buying decision when it comes to purchasing a product with fragrance finish. The target audience would be people over 15+ years of age, with no limitations to geographical location, income group and other personal factors.

Another topic covered in the survey is the acceptance of various scents that could be incorporated into products, so as to come up with all popular options. Pareto charts show most of the findings in an efficient manner.

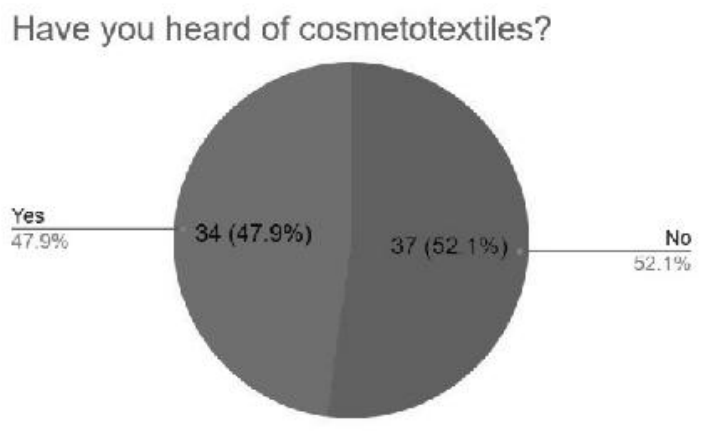

Figure 1: Awareness on cosmetotextiles amongst consumers

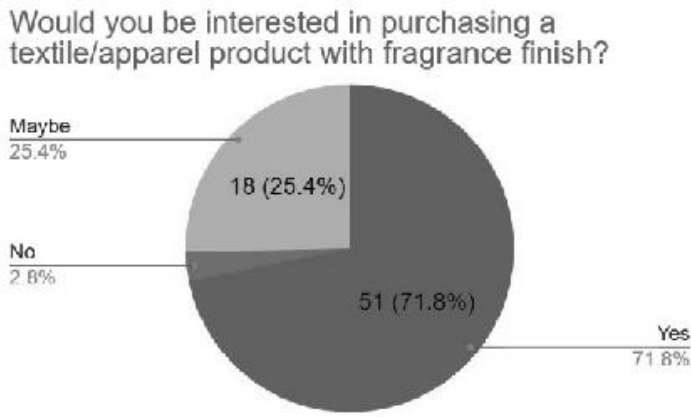

Figure 3: Acceptability of fragrance finished textile/apparel products

How much extra would you be willing to pay for such a product?

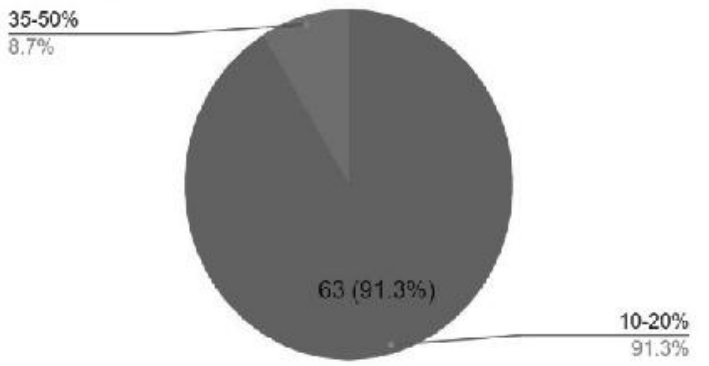

Figure 5: Value mapping for fragrance finished textile products
Chi square test was conducted for relating gender to acceptance of the product under discussion. It was also used for relating gender, income group \& age group to the buying decision of people.

\subsection{Research Deliverables}

- Market survey showing consumer acceptance

- Comparison of popularity of fragrances

- Identification of factors affecting buying decision

Have you come across any textile product with fragrance finish?

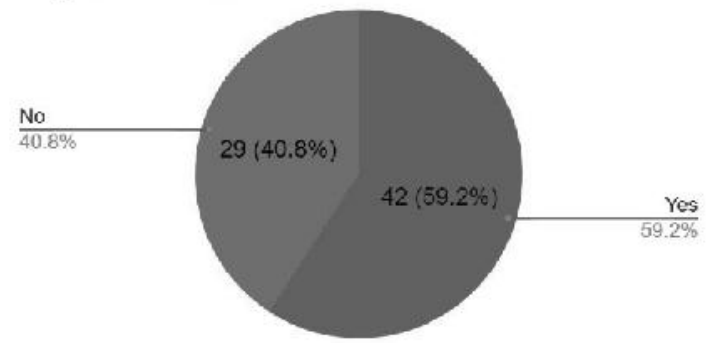

Figure 2: Awareness on fragrance finished textile products amongst consumer

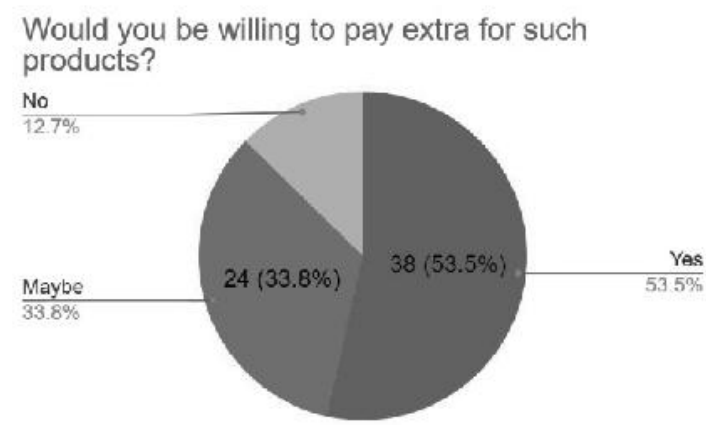

Figure 4: Value study for fragrance finished textile products

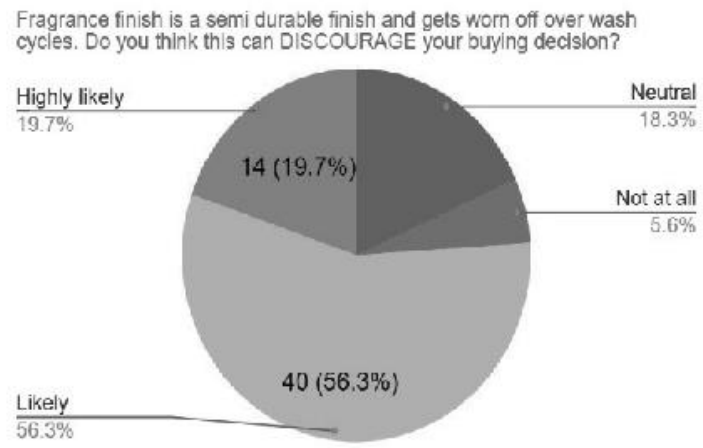

Figure 6: Buying behaviour with respect to durability of fragrance finishing on textiles 


\section{RESULTS AND DISCUSSION}

The responses received were from 71 people, from all around the country. Males responded more than females and the major age group to respond was people from 15-20 years of age.

Not many people know about cosmeto-textiles, yet are very willing to buy fabrics with fragrance finish. It is evident that the market acceptance of this product is quite good, even though the awareness isn't.

Using Chi-square test, it was found that family income also does not affect the buying decision of the person. It was observed that $72.2 \%$ people were interested in purchasing a textile/apparel product with fragrance finish. $25 \%$ were unsure about it, and the rest said No.

Only $54.2 \%$ were keen on paying extra for such a product, while $33.3 \%$ of them were unsure of it and $12.5 \%$ were not at all keen.

An important observation is that $91.4 \%$ of people would like to pay $10-20 \%$ extra for this product, with $8.6 \%$ willing to pay $35-50 \%$ and none offering to pay more than $50 \%$.

Considering that fragrance finish is a semi-durable finish, this nature of the finish made $19.4 \%$ people highly discouraged to buy the product and $56.9 \%$ somewhat discouraged. $18.1 \%$ of people were neutral about this and the rest weren't really affected by this.

Regarding popularity of fragrances, lavender and floral scents had the most supporters with $61.1 \%$ \& $59.7 \%$ votes respectively. These were followed by Mint, Citrus, Fruity and Green tea scents. These were the options given in the survey as they were out in the market already, but it was interesting to see responses with their own choice of scent, ranging from rose, vanilla to sandalwood and chocolate.

The categories most in demand with this finish were home/lifestyle products and socks, gloves, handkerchiefs with $69.4 \%$ and $51.4 \%$ votes respectively, followed by activewear (47.2\%) and intimate wear (45.8\%).

\subsection{Statistical Analysis}

Chi-square test was the statistical tool to analyze relationship between gender and income group to buying behaviour of consumers.

\subsubsection{Relationship between gender and buying behaviour}

Null hypothesis: Gender has no effect whatsoever on the buying behaviour of the consumer.
What sort of fragrance are you more likely to buy? (top 3 preferences)

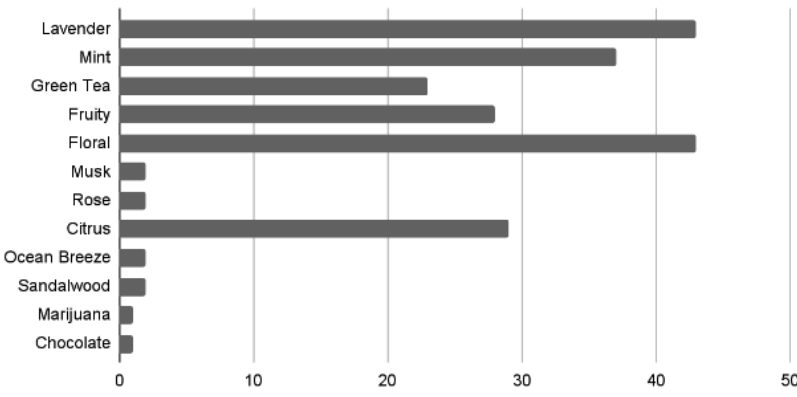

Figure 7: Fragrance preference study amongst consumers

In which of the following categories, would you prefer such type of product? (top 3 preferences)

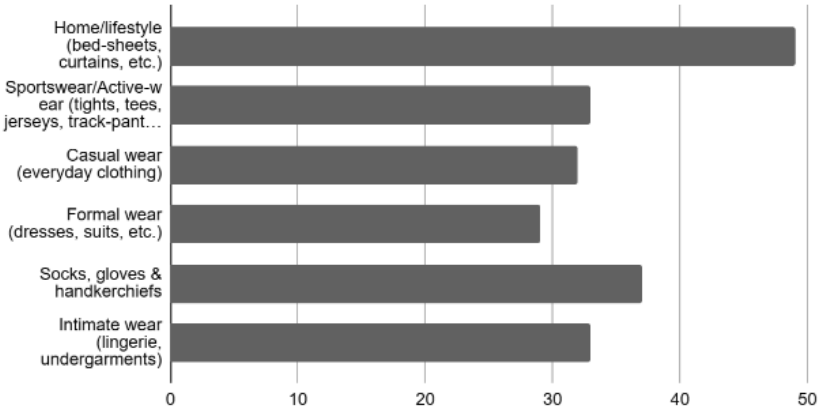

Figure 8: Textile product preference for fragrance finishing study amongst consumers

Observed values:

\begin{tabular}{|l|l|l|l|l|}
\hline Gender & Yes & No & Maybe & Total \\
\hline Male & 31 & 1 & 12 & 44 \\
\hline Female & 20 & 1 & 6 & 27 \\
\hline Total & 51 & 2 & 18 & 71 \\
\hline
\end{tabular}

Expected table:

\begin{tabular}{|l|l|l|l|}
\hline Gender & Yes & No & Maybe \\
\hline Male & 31.6 & 1.23 & 11.15 \\
\hline Female & 19.39 & 0.76 & 6.84 \\
\hline
\end{tabular}

$X^{2}$ Table:

\begin{tabular}{|l|l|l|}
\hline 0.011 & 0.043 & 0.064 \\
\hline 0.019 & 0.76 & 0.103 \\
\hline
\end{tabular}

$\mathrm{X}^{2}$ value $=0.315$

Degree of freedom $(a)=(2-1) *(3-1)=1 * 2=2$

Tabulated value $=5.991$

Since the calculated value is less than the tabulated value, we fail to reject the null hypothesis $(0.315<5.991)$

Hence, gender has no effect on the buying behaviour of the customer. 


\subsubsection{Relationship between income group and buying behaviour}

Null hypothesis: Income group has no effect whatsoever on the buying behaviour of the consumer.

Observed values:

\begin{tabular}{|l|l|l|l|l|}
\hline Income group & Yes & No & Maybe & Total \\
\hline Below 5 lacs & 26 & 0 & 4 & 30 \\
\hline 5-15 lacs & 17 & 1 & 11 & 29 \\
\hline $15+$ lacs & 8 & 1 & 3 & 12 \\
\hline Total & 51 & 2 & 18 & 71 \\
\hline
\end{tabular}

Expected table:

\begin{tabular}{|l|l|l|l|}
\hline Income group & Yes & No & Maybe \\
\hline Below 5 lacs & 21.54 & 0.845 & 7.60 \\
\hline 5-15 lacs & 20.83 & 0.81 & 7.35 \\
\hline 15+ lacs & 8.619 & 0.33 & 3.048 \\
\hline
\end{tabular}

$\mathrm{X}^{2}$ Table:

\begin{tabular}{|l|l|l|}
\hline 0.92 & 0.084 & 1.7 \\
\hline 0.704 & 0.044 & 1.81 \\
\hline 0.044 & 1.36 & 0.075 \\
\hline
\end{tabular}

$\mathrm{X}^{2}$ value $=7.49$

Degree of freedom $(a)=(3-1) *(3-1)=2 * 2=4$

Tabulated value $=9.487$

Since the calculated value is less than the tabulated value, we fail to reject the null hypothesis $(7.49<9.487)$

Hence, the income group has no effect on the buying behaviour of the customer.

While comparing the buying behaviour according to gender, the $X^{2}$ value was calculated to be 0.315 with a degree of freedom equal to 2 . Tabulated value was found to be 5.991 .

While comparing the buying behaviour according to income group, the $X^{2}$ value was calculated to be 7.49 with a degree of freedom equal to 4 . Tabulated value was found to be 9.487 .

For both cases, the calculated value was less than the tabulated value, hence failing to reject the null hypothesis.

Hence, gender and income have no effect on the buying behaviour of the consumer.

\section{CONCLUSION}

The global marketplace is continuously changing and so is the demand of consumers. With fragrance finishing, a whole new option of an "interactive" prod- uct will be given to consumers. Even though the research done in this area is quite extensive, there are questions that have been left unanswered.

The durability of fragrance finish on textile products remains a vague topic. As per many studies, it is evident that this type of a product only has the capacity to last a few washes.

The storage of such textiles also remains a big question as pointed out by one study [15]. It highlights the importance of proper wash care and handling instructions for products of such nature. Also, it is important to inform consumers to keep these products in isolation so as to avoid the mixing of scents from another product.

Value addition on textile substrates is playing a very important role in manufacturing of fabric. Having said that, fragrance finish being a fresh and interesting take on textiles, encouraging more experimentation and production in this domain. As shown in the study, consumers are open to using a product of this kind, regardless of their income group and gender. This widens the customer base a lot and showcases

With the right mix of fabric composition, construction, finishing and properties, we have great potential for this domain of new age textile products.

\section{ACKNOWLEDGEMENT}

Authors would like to claim that this work has no financial conflict of interest. A.K. would like to thank Mrs. Rashmi Thakur from the National Institute of Fashion Technology, Mumbai, India for imparting valuable knowledge which contributed immensely towards the completion of this paper. Special thanks to Mr. Akash Gaikwad, a student from the same institute, for his help in successfully carrying out the survey. G.K. would like to thank A.K. for providing him an opportunity to work on this paper.

\section{REFERENCES}

[1] Cussler, E. C., Moggridge G. D. (2001). Chemical Product Design, Cambridge University Press: Cambridge

[2] Wesselingh, J. A., Kill, S., Vild, M. E. (2007). Design \& Development of biological, chemical, food and pharmaceutical products, Wiley: Chichester, U.K.

[3] Wei, J. (2007). Product engineering. Molecular structure and properties, Oxford University Press: New York.

[4] Costa, R., Moggridge, G. D., Saraiva, P. M. (2006) Chemical product engineering: an emerging 
paradigm within chemical engineering. AIChE Journal, 52 (6)

[5] Bernardo, F., Costa, R., Saraiva, P. M., Moggridge, G. D. (2007). Chemical product engineering and design: active learning through the use of case studies. International Conference in Engineering Education ICEE 2007, Coimbra, Portugal, September 3-7, 2007.

[6] María M. Miró Specos \& Germán Escobar. (2010). Aroma Finishing of Cotton Fabrics by Means of Microencapsulation Techniques, Journal of Industrial Textiles, 1, 13-32.

[7] D. Vasanth Kumar, N. Boopathi, N. Karthick, P. Ramesh (2012). Aesthetic Finishes for Home Textile Materials International Journal of Textile Science, 1(3), 5-9

[8] Rodriguez-Gil, G. The Sense of Smell: A Powerful Sense

(http://www.sfsu.edu/ cadbs, available: 02/05/2020)

[9] Biswas, D., Chakrabarti, S. K., Saha, S. G., Chatterjee, S. (2015). Durable fragrance finishing on jute blended home-textiles by microencapsulated aroma oil. Fibers and Polymers, 16(9), 1882-1889.

[10] Buchbauer, G. (1993). Fragrance compounds and essential oils with sedative effects upon inhalation, American Pharmaceutical Association. 52, 560-664.

[11] John Pierce, leader; Fernando Tovia; Natalie Weathers (Phila U). (2006). Scent-Infused Textiles to Enhance Consumer Experiences, National Textile Center Research Briefs-Fabrication Competency

[12] D. Vasanth Kumar, N. Boopathi, N. Karthick, P. Ramesh (2012). International Journal of Textile Science, 1(3), 5-9.

[13] Mendapara, S., Karolia, A. (2005). Application of Antimicrobial and Fragrance Finish in Combination by Microencapsulation on Cotton Fabric, Journal of the Textile Association, 66(4), 155-159

[14] W D Schindler, P J Hauser. (2004). Chemical Finishing of Textiles, Woodhead publishing in Textiles: Woodhead Publishing Limited.

[15] Dr. A. J West, Dr. K. E. Annett-Hitchcock (2014). A Critical Review of Aroma Therapeutic Applications for Textiles.

[16] Aromatherapy: the search for 'stress solutions'. Global Cosmetic Industry, 2000, 166:167.

[17] Jellinnek, J. S. (1994). Aromachology: A Status Review. Perfume \& Flavorist. 19, 25-49.

[18] Wu Chao-Hsiang. (1999). Essential Oil and Aromatherapy, Kexue Nong Ye. 47(3), 1-3

[19] Buchbauer, G. (1996). Methods in Aromatherapy Research. Perfume \& Flavorist, 21, 31-36.
[20] Buchbauer, G. (1993). Therapeutic Properties of Essential Oils and Fragrance. Bio-active Volatile Compounds from Plants. 25,159-165.

[21] Schnaubelt, K. (1995). Essential oils-Viable Holistic Pharmaceuticals for the Future. Flavors, Fragrance and Essential Oils. Proceedings of the 13th International congress of Flavors, Fragrance and Essential oils. 3, 15-19.

[22] Martin, G. N. (1996). Olfactory remediation: Current evidence and possible applications. Social Science \& Medicine, 43(1), 63-70.

[23] Mazzaro, D. (2000). The home fragrance market. Chemical Market Reporter, August 4-14.

[24] Stevensen, C. J. (1998). Aromatherapy in dermatology. Clinics in Dermatology, 16, p.689-694.

[25] Johansen, K. (2008). Perfumed textiles. Textile Society of America 11th Biennial Symposium: Textiles as Cultural Expressions, Honolulu, Hawai'i.

[26] Karolia, Anjali Mendapara, Snehal.(2007). Imparting antimicrobial and fragrance finish on cotton using chitosan with silicon softener, Indian Journal of Fibre \& Textile Research. 32, 99-104

[27] Singh, Nagender, Yadav, Manisha, Khanna, Shelly, Sahu, Omprakash. (2017). Sustainable fragrance cum antimicrobial finishing on cotton: Indigenous essential oil. Sustainable Chemistry and Pharmacy. $5,22-29$

[28] John Max, Philip Joseph. (2014). Chemical Finishing in textile products. Asian Dyer. 09, 45-49.

[29] Periyasamy, Aravin Prince. (2012). Bio Finishing of Fabrics. Asian Dyer. 09. 45-49.

[30] Banupriya J, Maheshwari V. (2013). Effects of Aromal Finish by Herbal and Conventional Methods on Woven Fabrics. J Textile Sci Eng, 3(138), 2.

[31] Patil DK, Agrawal DS, Mahire RR, More DH. (2016). Synthesis, characterization and controlled release studies of ethyl cellulose microcapsules incorporating essential oil using an emulsion solvent evaporation method, American Journal of Essential Oils and Natural Products, 23-31.

[32] Dubey R, Shami TC, Bhasker Rao KU. (2009). Microencapsulation technology and applications. Defence Science Journal. 82-95.

[33] Jellinnek, J. S. (1994). Aromachology: A Status Review. Perfume \& Flavorist.19, .25-49.

[34] Wu Chao-Hsiang. (1999). Essential Oil and Aromatherapy, Kexue Nong, 47(3), 1-3.

[35] Mazzaro, D. (2000). The home fragrance market. Chemical Market Reporter, 4-14. 


\section{ANNEXURE}

\section{Survey questions \& options}

a) Email ID

b) Gender
a. Male
b. Female
c. Transgender
d. Prefer not to mention

c) Age group
a. 15-25 years
b. 25 -35 years
c. $35-50$ years
d. 50 years and above

d) Family Income (p.a)
a. Less than 2.5 lacs
b. 2.5-5 lacs
c. 5-10 lacs
d. 10-15 lacs
e. 15 lacs and above

e) Have you heard of cosmetotextiles?
a. Yes
b. No

f) Have you come across textile product with fragrance finish?
a. Yes
b. No

g) Would you be interested in purchasing a textile/apparel product with fragrance finish?
a. Yes
b. No
c. Maybe

h) Would you be willing to pay extra for such products?
a. Yes
b. No
c. Maybe

i) How much extra would you pay willingly?
a. $10-20 \%$
b. $20-35 \%$
c. $35-50 \%$
d. $50 \%$ and up

j) Fragrance finish is a semi durable finish and gets worn off over wash cycles. Do you think this can discourage your buying decision?
a. Highly likely
b. Likely
c. Neutral
d. Not likely
e. Least likely

k) What sort of fragrance are you more likely to buy? (top 3 preferences)
a. Lavender
b. Citrus
c. Mint
d. Fruity
e. Green tea
f. Others (please specify)

I) In which of the following categories, would you prefer such type of product? (top 3 preferences)
a. Home / lifestyle (bedsheets, upholstery, tablecloths, curtains)
b. Sportswear/ Activewear (tights, tracks, tees, jerseys)

c. Casual wear

d. Formal wear

e. Socks \& gloves

f. Intimate wear / undergarments
Primljeno/Received on: 04.10.2021

Revidirano/ Revised on: 24.11.2021

Prihvaćeno/Accepted on: 25.11.2021.

\footnotetext{
2021 Authors. Published by Union of Textile Engineers and Technicians of Serbia. This article is an open access article distributed under the terms and conditions of the Creative Commons Attribution 4.0 International license (CC BY) (https://creativecommons. org/licenses/by/4.0/)
} 